\title{
Computer models as social learning tools in participatory integrated assessment
}

Citation for published version (APA):

de Kraker, J., Kroeze, C., \& Kirschner, P. (2011). Computer models as social learning tools in participatory integrated assessment. International Journal of Agricultural Sustainability, 9(2), 297-309. https://doi.org/10.1080/14735903.2011.582356

Document status and date:

Published: 01/05/2011

DOI:

10.1080/14735903.2011.582356

Document Version:

Publisher's PDF, also known as Version of record

Document license:

Taverne

Please check the document version of this publication:

- A submitted manuscript is the version of the article upon submission and before peer-review. There can be important differences between the submitted version and the official published version of record.

People interested in the research are advised to contact the author for the final version of the publication, or visit the DOI to the publisher's website.

- The final author version and the galley proof are versions of the publication after peer review.

- The final published version features the final layout of the paper including the volume, issue and page numbers.

Link to publication

\footnotetext{
General rights rights.

- You may freely distribute the URL identifying the publication in the public portal. please follow below link for the End User Agreement:

www.umlib.nl/taverne-license

Take down policy

If you believe that this document breaches copyright please contact us at:

repository@maastrichtuniversity.nl

providing details and we will investigate your claim.
}

Copyright and moral rights for the publications made accessible in the public portal are retained by the authors and/or other copyright owners and it is a condition of accessing publications that users recognise and abide by the legal requirements associated with these

- Users may download and print one copy of any publication from the public portal for the purpose of private study or research.

- You may not further distribute the material or use it for any profit-making activity or commercial gain

If the publication is distributed under the terms of Article $25 \mathrm{fa}$ of the Dutch Copyright Act, indicated by the "Taverne" license above, 


\section{Computer models as social learning tools in participatory integrated assessment}

Joop de Kraker , Carolien Kroeze \& Paul Kirschner

To cite this article: Joop de Kraker , Carolien Kroeze \& Paul Kirschner (2011) Computer models as social learning tools in participatory integrated assessment, International Journal of Agricultural Sustainability, 9:2, 297-309, DOI: 10.1080/14735903.2011.582356

To link to this article: https://doi.org/10.1080/14735903.2011.582356

\section{Published online: 15 Jul 2011.}

Submit your article to this journal $\sqsubset$

Lll Article views: 353

Q View related articles $\asymp$

4 Citing articles: 8 View citing articles 준 


\title{
Computer models as social learning tools in participatory integrated assessment
}

\author{
Joop de Kraker ${ }^{1 *}$, Carolien Kroeze ${ }^{1}$ and Paul Kirschner ${ }^{2}$ \\ ${ }^{1}$ School of Science, Open University of the Netherlands, P.O. Box 2960, 6401 DL Heerlen, The Netherlands \\ ${ }^{2}$ Centre for Learning Sciences and Technology (CELSTEC), Open University of the Netherlands, P.O. Box 2960, 6401 DL \\ Heerlen, The Netherlands
}

Participatory integrated assessment (PIA) is a structured process conducted with stakeholders to assess the environmental, economic and social dimensions of a complex issue and the impacts of policy choices. PIA may result in social learning - a convergence in the stakeholders' perspectives on the problem and its solutions - which creates a basis for more sustainable, collective action. This paper addresses the role of computer models used in integrated assessment in supporting social learning and discusses a selection of model-based PIA projects. We argue that models may play two important roles. First, with models the consequences of options can be explored turning the PIA process into an experiential learning cycle for the stakeholders. Second, models provide a platform and structure for stakeholders to communicate, negotiate and integrate their perspectives. However, in many PIA projects, computer models fail to play a significant supporting role in social learning. Experiences with other participatory modelling approaches indicate that a higher degree of stakeholder involvement in model development can increase the effectiveness of models as social tools. This, however, is time- and resource-intensive and difficult to scale up but insights from collaborative learning science and technology may help to enhance the effectiveness and efficiency of PIA model in supporting social learning.

Keywords: computer models; participatory integrated assessment; participatory modelling; social learning

\section{Introduction}

Many of the major sustainability issues in environmental and resources management are presently defined as 'wicked' (Rittel and Webber, 1973) or 'unstructured' problems (Hisschemöller and Hoppe, 1995). Such problems are hard to manage, because they extend over multiple scales and dimensions, the environmental dimension being tightly interwoven with the social and economic dimensions. As a consequence, they are surrounded by structural uncertainties and involve many interdependent stakeholders with often diverging or even conflicting interests and perspectives on what the problem actually is as well as on possible ways to solve it. A typical example is the current issue of climate change. To produce knowledge relevant to the management of such complex problems, scientists need integrated approaches that include multiple types of expertise and multiple viewpoints. Integrated assessment (IA) is a major example of such an approach (Harris, 2002). It is a structured process to assess the environmental, economic and social dimensions of a complex issue and the impacts of policy responses to it. IA explicitly aims to make these integrated insights available to decision makers, using knowledge from various disciplines and sources (Rotmans, 1998). Computer models allowing for the simulation and examination of complex and dynamic systems have traditionally been a major tool in IA for knowledge integration and quantitative explorations of trends and impacts (Rotmans, 1998). In IA of climate change, where the roots of IA lie, such models have even become the dominant means of scientific knowledge production. Over the past decades, the application of IA has spread outside the area of climate change to other issues such as transboundary air pollution 
(Amann et al., 1999), water resources management (Pahl-Wostl, 2002), land use (Kok et al., 2007) and, recently, agricultural sustainability (van Ittersum et al., 2008).

\section{Box 1 Definitions of terms}

Integrated assessment (IA): a structured process to assess the environmental, economic and social dimensions of a complex issue and the impacts of policy responses to it. IA explicitly aims to make these integrated insights available to decision makers, using knowledge from various disciplines and sources.

Participatory integrated assessment (PIA): integrated assessment involving stakeholders, whereas the degree of involvement may range from low to high and may differ per assessment phase. The assessment is assumed to be computer-model-based and future oriented.

Stakeholders: individuals representing their own or their organization's interest in the problem to be assessed. Stakeholders may include government officials or other decision makers, but scientists conducting the assessment are not included. This is not because they may not have any stake in the issue, but because they perform a different role in the PIA process.

Decision makers: those with any degree of formal decision power over the system on which the assessment focuses. Depending on the type of system (public or private), synonyms used are policy makers, administrators, managers.

Options: possible ways to solve the problem. Depending on the type of problem, synonyms used are possible solutions, policy options, policies, choices, decision alternatives, alternative (management) strategies.

Recommendations: insights representing the outcome of the assessment for decision makers. Often the focus is on the preferred way to solve the problem, e.g. a set of selected policy options or management strategies. Includes action or management plans, policy advice. It may also take the form of a recommended design of a policy or management experiment.

Computer model: formal, quantitative models, representing a system with a set of mathematical equations. The term does include various forms of quantitative models, such as process-oriented simulation models and goal-oriented optimization models, but does not refer to qualitative, graphical models, which may also be computer-based. Also includes system model, IA model, integrated model and dynamic model.

Social learning: a process of convergent change in the stakeholders' perspectives on the problem, possible solutions and risks, as well as their own and the other stakeholders' position with regard to solving the problem.
After about a decade of IA research and development, major proponents of this approach have come to the conclusion that the impact of IA on decision making had been fairly limited (Rotmans, 2006). To improve its contribution, IA is increasingly being conducted in close interaction with policy makers and societal stakeholders. Such a participatory approach may (1) improve the quality of the assessment by including relevant non-scientific sources of knowledge and experience, (2) enhance its relevance, legitimacy and credibility by accounting for the diversity in perspectives on the problem and possible solutions among the stakeholders, and thus (3) increase the basis of support for the outcomes of the assessment (Hisschemöller et al., 2001; Kloprogge and van der Sluijs, 2006). An aspect of participatory integrated assessment (PIA) that has recently received considerable attention is social learning of stakeholders, that is, a process of reframing and convergence of their perspectives on the problem and possible solutions. From the perspective of sustainable development, social learning is a desirable outcome, as it creates the basis for integrated solutions that require collective support and concerted action of multiple stakeholders (Röling, 2002). This raises the question as to whether and how computer models that have such a central place in IA can function as tools to stimulate and support social learning among stakeholders. This paper addresses the various support roles that computer models may have in social learning in IAs. To this end, we discuss a selection of model-based PIA projects. In Box 1, the set of terms used in this paper are defined and synonyms found in the source publications are given.

\section{Learning in PIA}

Stakeholder participation in PIA takes many different forms. A common way of classifying PIA projects is according to the degree of stakeholder involvement in terms of decision-making authority, inspired by Arnstein's famous 'ladder of citizen participation' (Arnstein, 1969). Volkery et al. (2008) translated the five rungs of this ladder to the PIA context as informing, consulting, co-designing, co-deciding and stakeholders deciding. In PIA, decision making concerns the design of the process as well as which knowledge is included in the products. The lowest degree of participation, scientists informing stakeholders, represents a situation in which scientists are completely in control of the process and only include scientific 
knowledge. The next rung on the ladder, scientists consulting stakeholders, represents a situation in which stakeholders provide input upon request, but scientists decide whether and how to use it. Co-designing, or co-producing, represents probably the most common interpretation of stakeholder participation in IA. Stakeholders are actively involved and contribute to the process or the product, but the scientists remain responsible. At the two highest rungs of the participation ladder, stakeholders are partially or fully in charge of the design of the process and the products. The latter situation is unlikely however in the case of PIA, which is typically initiated by scientists.

The various degrees of stakeholder participation in PIA can also be characterized in terms of knowledge exchange (Hage and Leroy, 2007), ranging from a unidirectional flow from scientists to stakeholders (informing) or from stakeholders to scientists (consulting), to a process of mutual exchange (co-producing, co-deciding, stakeholders in charge). Likewise, the dominant type of learning interaction in the PIA process also differs with the rungs of the participation ladder. Learning interactions range from stakeholders learning from scientists (informing) or vice versa (consulting), mutual or co-learning of scientists and stakeholders (co-producing), to scientists mainly supporting mutual learning among stakeholders (co-deciding, stakeholders deciding) (van de Kerkhof, 2006; Bohunovsky and Jäger, 2008; Tuinstra et al., 2008). When learning concerns acquiring new technical knowledge and insights on, for example, effective policy instruments or important constraints, we speak of instrumental or 'single-loop' learning. Learning may also concern the underlying assumptions, norms and goals that determine how participants frame and define the problem. When the interactions in a PIA project result not only in a change in instrumental knowledge, but also in a change in the participants' perspective on the problem and consequently the possible solutions, we speak of reframing or 'double-loop' learning. Some authors distinguish a third order of learning, transformative or 'triple-loop' learning, when the deeply held beliefs and core values of participants change (e.g. Keen et al., 2005; Pahl-Wostl, 2009). More often however, changes in beliefs, values, norms and goals are taken together as 'double-loop' learning, with the implicit assumption that people's core values and beliefs are quite stable and unlikely to change in the context of a PIA (cf. Sabatier, 1988). The concepts of single- and double-loop learning were coined by Argyris and Schön (1978) and refer to the feedback loops in a learning process. In singleloop learning there is only one loop of error correction, that is, between actions and their outcomes. Actions are changed when they do not have the desired outcomes, without questioning or altering the existing framework of objectives and causal beliefs underlying the actions. In double-loop learning, a second feedback loop is added when the perceived range of options does not result in desired outcomes. In this feedback loop, the underlying frame of values, objectives, norms and beliefs is included in the learning process. In cases where double-loop learning takes place among the participants of a PIA, their individual perspectives might not only change, but this change might be convergent in the sense that the perspectives become (more) similar and overlapping as a result of the interactions in the group. In the literature on sustainable environmental and resource management (e.g. Leeuwis and Pyburn, 2002; Keen et al., 2005; Wals, 2007) and IA (Tuinstra et al., 2008), this phenomenon is commonly referred to as 'social learning'.

The concept of social learning is interpreted and applied in diverse ways. For example, 'change' may include not only cognitive change, but also change in behaviour and institutional arrangements and the 'group' at stake may include multiple stakeholders or peers (Leeuwis et al., 2002). In the context of PIA, we consider social learning as a process of social-cognitive and social-relational change in a diverse group of stakeholders supported by scientists. In the social-cognitive dimension, there is a convergent change in the stakeholders' perspectives on the problem, possible solutions and risks as well as their own and the other stakeholders' position and responsibility with regard to solving the problem (Leeuwis, 2002). Change in the social-relational dimension involves the development of social capital, such as trust, improved communication and better working relations (Pahl-Wostl and Hare, 2004). In PIA, the substantive outcome of social learning will be a collectively supported decision, strategy or policy advice. As for IA, this is the end-product. It is hoped, of course, that this may be followed by a sequence of other, even more substantive outcomes, such as changes in stakeholder behaviour at individual and institutional level, concerted or collective implementation of planned actions (including changes in institutional arrangements), and better, more sustainable environmental and resources 
management. Muro and Jeffrey (2008) conducted a critical review of claims and outcomes of social learning and listed many factors fostering social learning, such as stakeholder selection (Prell et al., 2006; Cuppen et al., 2010). This paper concentrates on the supporting role of models in social learning. The following sections discuss whether and how the computer models typically used in IA can serve as tools for social learning, with a focus on the social-cognitive dimension.

\section{Computer models as social learning tools}

Computer models allowing for the simulation and examination of complex and dynamic systems are major tools in IA (Rotmans, 1998; see Lotze-Campen (2007) for an extensive overview of IA models). In IA such models mainly serve to (1) integrate knowledge from a variety of scientific disciplines and sources and provide a common, interdisciplinary understanding of complex environmental problems, (2) analyse the causes and impacts of these problems across multiple scales of time and space, and (3) explore and assess policy and management options and their trade-offs (Siebenhüner and Barth, 2005). A model-based IA may broadly be divided into a pre-modelling phase, a modelling phase and a post-modelling phase (Ewert et al., 2009), although these phases are not at all strictly separated, as many PIA projects follow an iterative and cyclic process. During each phase and step, the role of stakeholders in PIA may range from passively providing inputs when asked for or actively bringing in their knowledge and perspectives, to having full responsibility for a step, such as scenario development (Volkery et al., 2008). The premodelling phase ideally results in clear specifications of the structure and functionalities of the quantitative computer model to be developed in the next phase. This requires the steps of problem description, system description, scenario development and formulation of options. In the modelling phase, the system as defined in the previous phase is examined quantitatively. The aim is to gain a better understanding of the system's behaviour, in particular how it responds to the external drivers defined in the scenarios and to the selected range of options. The qualitative descriptions of the system, scenarios and options must therefore be translated into a quantitative computer model and input data. The post-modelling phase deals with the outcomes of the modelling phase and includes three major steps: visualization of model results, evaluation of options and formulation of recommendations. Frequent iterations between the evaluation step and the steps in the pre-modelling phase represent the essence of the assessment procedure and provide the crucial feedback link between choices and consequences. With this feedback link, the PIA process resembles Kolb's experiential learning cycle (Kolb, 1984). In this cycle, the learner moves from experiencing the effects of actions to reflecting on these effects, from reflecting to (re)conceptualizing the relation between actions and effects and generalizing these to theory. The learner may then decide on new actions based on the adapted theory, and the experiences that follow from these actions start another learning cycle. Social learning has been defined as an interactive process of shared, experiential learning, amplified by facilitated communication and dialogue (Jiggins et al., 2007). From this perspective, the major support functions of models in social learning in PIA can be summarized as follows. First, models help to close the learning cycle by supporting the essential feedback loop from actions through (simulated) experience and reflection to reconceptualization. Second, models as external representations of the problem (and the system) can help to support communication and dialogue among stakeholders to make it an interactive, shared learning process.

\section{Social learning in model-based PIA projects}

In the literature on PIA and related approaches employing a participatory modelling approach, frequent references can be found to the role of computer models as tools to support stakeholder learning, communication, discussion, negotiation or consensusbuilding. Explicit analyses of the role of these models in supporting social learning are rare, however, and evidence of learning outcomes is hardly ever presented to support conclusions that learning had taken place, other than self-reported learning. Our discussion about model-based support of social learning in the reviewed cases below is therefore mainly based on our own interpretation of the published information. The cases are selected through a search of the published literature on the grounds of being integrative and future-oriented in scope, participatory by involving a diversity of stakeholders, and focused on more sustainable environmental and 
resource management strategies and policies, using computer-model-based assessments. The main features of the nine selected model-based PIA projects are summarized in Table 1. The cases are presented below in chronological order.

\section{Rains}

The 'regional air pollution information and simulation' (RAINS) model has already been used since the 1980s to support international negotiations under the convention on long-range transboundary air pollution in Europe (Amann et al., 1999). The stakeholders in this case are delegates from various countries, using the model to learn about relevant emission reduction targets and cost-effective strategies to reach these targets (Tuinstra et al., 1999). In the early 1990s, a number of novel concepts were introduced into the negotiations separately from the model, such as the 'critical load' concept, which did lead to a collective reframing of the perspectives of delegates and a breakthrough in the negotiations (Siebenhüner, 2002). The RAINS model was adapted to

Table 1 | Main features of nine model-based PIA projects. See text for a detailed discussion of cases and references

\begin{tabular}{|c|c|c|c|c|}
\hline Project & Area & Objective & Stakeholders & Intended model use \\
\hline RAINS & $\begin{array}{l}\text { Transboundary } \\
\text { air pollution }\end{array}$ & $\begin{array}{l}\text { Support international } \\
\text { negotiations }\end{array}$ & $\begin{array}{l}\text { Delegates from European } \\
\text { countries }\end{array}$ & $\begin{array}{l}\text { Identification of } \\
\text { cost-effective emission } \\
\text { reduction strategies }\end{array}$ \\
\hline Delft process & Climate change & $\begin{array}{l}\text { Support preparations for } \\
\text { Kyoto negotiations }\end{array}$ & $\begin{array}{l}\text { Policy makers from } \\
\text { European and developing } \\
\text { countries }\end{array}$ & $\begin{array}{l}\text { Assessment of long-term } \\
\text { impacts of climate policy } \\
\text { measures }\end{array}$ \\
\hline ULYSSES & Climate change & $\begin{array}{l}\text { Inform regional policy } \\
\text { making with citizen } \\
\text { assessment }\end{array}$ & Citizen focus groups & $\begin{array}{l}\text { Explanation of the problem } \\
\text { and exploration of regional } \\
\text { mitigation options }\end{array}$ \\
\hline QUEST & $\begin{array}{l}\text { Regional } \\
\text { development }\end{array}$ & $\begin{array}{l}\text { Stimulate development of } \\
\text { long-term, sustainable } \\
\text { policy at regional level }\end{array}$ & $\begin{array}{l}\text { Local government policy } \\
\text { makers and technical staff; } \\
\text { community members }\end{array}$ & $\begin{array}{l}\text { Definition of 'desirable } \\
\text { futures' in long-term goals } \\
\text { and exploration of } \\
\text { consequences }\end{array}$ \\
\hline $\begin{array}{l}\text { VISIONS } \\
\text { (Green Heart } \\
\text { case) }\end{array}$ & $\begin{array}{l}\text { Regional } \\
\text { development, } \\
\text { land use }\end{array}$ & $\begin{array}{l}\text { Inform spatial planning } \\
\text { policy with integrated } \\
\text { scenarios }\end{array}$ & $\begin{array}{l}\text { Representatives from } \\
\text { research, policy, business } \\
\text { and NGO sectors; } \\
\text { inhabitants }\end{array}$ & $\begin{array}{l}\text { Underpinning/visualizing } \\
\text { storylines with } \\
\text { quantitative, spatially } \\
\text { explicit simulations }\end{array}$ \\
\hline $\begin{array}{l}\text { HarmoniCOP } \\
\text { (Flemish } \\
\text { case) }\end{array}$ & $\begin{array}{l}\text { Water } \\
\text { resources } \\
\text { management }\end{array}$ & $\begin{array}{l}\text { Develop new river basin } \\
\text { management strategy }\end{array}$ & $\begin{array}{l}\text { 'Interested parties’: e.g. } \\
\text { administrators, farmers, } \\
\text { environmentalists }\end{array}$ & $\begin{array}{l}\text { Assessment of strategies } \\
\text { concerning flooding } \\
\text { hazards and ecological } \\
\text { impacts }\end{array}$ \\
\hline ATEAM & $\begin{array}{l}\text { Ecosystem } \\
\text { management }\end{array}$ & $\begin{array}{l}\text { Inform policy with } \\
\text { assessment of } \\
\text { vulnerability of European } \\
\text { ecosystems to global } \\
\text { change }\end{array}$ & $\begin{array}{l}\text { Policy advisors and sectoral } \\
\text { representatives (e.g. } \\
\text { tourism, forestry, } \\
\text { agriculture, nature } \\
\text { conservation) }\end{array}$ & $\begin{array}{l}\text { Quantify and map impacts } \\
\text { of global change on } \\
\text { provision of ecosystem } \\
\text { services }\end{array}$ \\
\hline PRELUDE & Land use & $\begin{array}{l}\text { Engage policy makers in } \\
\text { discussion about } \\
\text { long-term developments } \\
\text { and response strategies }\end{array}$ & $\begin{array}{l}\text { Policy makers, researchers, } \\
\text { representatives of interest } \\
\text { groups, independent } \\
\text { thinkers }\end{array}$ & $\begin{array}{l}\text { Underpinning/visualizing } \\
\text { storylines with } \\
\text { quantitative, spatially } \\
\text { explicit simulations }\end{array}$ \\
\hline $\begin{array}{l}\text { Sustainable } \\
\text { uplands }\end{array}$ & $\begin{array}{l}\text { Ecosystem } \\
\text { management }\end{array}$ & $\begin{array}{l}\text { Develop choice of options } \\
\text { for sustainable rural } \\
\text { development }\end{array}$ & $\begin{array}{l}\text { Local policy makers, land } \\
\text { managers, water } \\
\text { companies, } \\
\text { environmentalists, } \\
\text { recreational groups }\end{array}$ & $\begin{array}{l}\text { Visualizing scenarios and } \\
\text { assessment of options } \\
\text { with quantitative, spatially } \\
\text { explicit simulations }\end{array}$ \\
\hline
\end{tabular}


support the operationalization of these new concepts with calculations. As such, the model did not function as a social learning tool, but more as an instrumental learning tool.

\section{Delft process}

In the Delft Process, the 'Integrated Model to Assess the Global Environment' (IMAGE) model for climate change assessment (Bouwman et al., 2006) was used to support policy makers from European and developing countries in their preparations for the negotiations leading up to the Kyoto protocol (van Daalen et al., 1996). Initially, there appeared to be a mismatch between the long-term orientation of the IMAGE model and the focus on short-term policy decisions of the participants. A breakthrough and collective reframing was achieved with the introduction of the 'safe landing' concept, which tracks long-term climate goals back to present needs for policy measures. This re-orientation made the model relevant to the participants, who then used it to learn more about the various impacts associated with longterm goals in climate policy (Stalpers et al., 2009). In the Delft process, the IMAGE model thus mainly served for single-loop learning, although it may have played a role in stimulating discussions and perhaps social learning on the value-laden assumptions behind the criteria for a 'safe landing' in terms of critical impact indicator values.

\section{ULYSSES}

The 'Urban Lifestyles, Sustainability and Integrated Environmental Assessment' (ULYSSES) project pioneered PIA with heterogeneous focus groups of citizens. These groups met for five sessions to debate climate change and to produce a citizen assessment report on regional impacts, policy goals and options for mitigation (Kasemir et al., 2000). The process was facilitated by a group moderator and a model moderator, assisting in the use of different computer models to support the debate. These models ranged from complex global models to simple accounting tools (Dahinden et al., 2000). Analyses of the role of the computer models suggest that the models were successful at conveying the temporal and spatial scale of climate change, the complexity of the system and the uncertainties in our understanding of it. However, most participants felt that the computer models were less instrumental for the exploration of policy options. This was caused by a range of factors, such as insufficient user-friendliness, lack of transparency and considerable complexity of the models, which usually made direct interaction impossible. Another reason was that the models could not support the type of assessments the participants were most interested in, that is, with a spatial focus on their own region, a time horizon of 10-20 years and assessment of feasibility of options rather than just effectiveness (Dahinden et al., 2000). An exception was the personal $\mathrm{CO}_{2}$ calculator, a simple tool to relate $\mathrm{CO}_{2}$ emissions to lifestyle choices produced at the request of participants in the Swiss case study (Schlumpf et al., 1999). It proved a good tool to support discussions, but these were primarily focused on options to cut personal $\mathrm{CO}_{2}$ emissions. With Siebenhüner and Barth (2005), we conclude that model-supported learning in ULYSSES concerned primarily single-loop learning about the problem and personal options to contribute to a solution. Given the problematic interaction with the computer models and the short time frame of the focus group workshops, significant changes in individual values seem unlikely. Moreover, although the model interaction did stimulate the debate around issues of ethical values and causal beliefs, "it is also possible that such a productive discussion would have taken place simply by bringing the topic to the table with some overheads or by talking' (Dahinden et al., 2000).

\section{QUEST}

QUEST is an interactive computer simulation tool to set long-term goals for sustainable regional development and explore the consequences of these 'desirable futures' (Carmichael et al., 2004). It was used in the Georgia Basin Futures Project in Canada, which aimed explicitly to stimulate dialogue and social learning on 'what sustainability means in concrete terms for a given context' (Robinson, 2003). The PIA part of the project consisted of half-day workshops in three municipalities with local policy makers, technical government staff and interested members of the community. Interaction with QUEST appeared to result in double-loop learning of individual participants, developing a more holistic view of sustainability (Shapka et al., 2008). In the workshops, after QUEST was shut down, stakeholders had lively discussions on questions of implementation and proposed action (Robinson et al., 2006). In this way, QUEST may stimulate social learning, but whether this actually occurred was not evaluated and seems unlikely, given that no collective outcomes were requested and given the very short duration of the interaction. This allowed 
only one or two iterations between choices and consequences with QUEST and no feedback from discussions on proposed actions to the definition of 'desirable futures' in QUEST. Interaction with QUEST was further hampered by mismatches between the expectations of the stakeholders and what the model could deliver in terms of spatial resolution (local vs. regional) and function (planning tool vs. visioning tool).

\section{VISIONS}

The 'Integrated visions for a sustainable Europe' (VISIONS) project was one of the first in developing and testing a participatory methodology for developing scenarios for IA studies. In the project, integrated scenarios for sustainable development pathways were developed for Europe as a whole and for three specific regions in Europe in a dialogue between scientists and a range of stakeholders (Rotmans et al., 2000). Computer models were used to underpin the scenarios quantitatively. For example, for the 'Green Heart' case (the Netherlands), a spatially explicit simulation model was developed, based on indicators selected by the stakeholders, to explore dynamic spatial trends and patterns associated with the storylines. The outcomes were discussed with the stakeholders in the next workshop (Rotmans et al., 2000). Stakeholder learning related to the computer models remained single-loop in this project, since the participants learned about the implications of scenarios and causal connections, but a thorough reflection process that included changes in perspective was not reported by the project team (Siebenhüner and Barth, 2005). A reason for this may have been the focus of stakeholders on intangible issues, such as cultural identity, quality of life, social cohesion and institutional changes, which could not be captured in the quantitative computer models (Rotmans et al., 2000). In the MedAction project, an IA of policies to combat desertification in the northern Mediterranean, the scenarios and methodology of the VISIONS project were further developed and adapted. Social learning was adopted as an explicit objective of the participatory scenario development and backcasting workshops with local stakeholders (Patel et al., 2007). However, computer models did not play a role in this process, partly because of technical difficulties in translating qualitative storylines into quantitative model input (Kok and van Delden, 2009), and partly because it was feared that modelbased quantification would hamper social learning by creating a false sense of certainty and objectivity (Patel et al., 2007).

\section{HarmoniCOP}

The 'Harmonising Collaborative Planning' (HarmoniCOP) project was one of the many European research projects that accompanied the introduction of the European Water Framework Directive (2000/ $60 / \mathrm{EC}$ ), which emphasizes 'the involvement of all interested parties' in the development of river basin management plans. The project investigated the importance of social learning and the supporting role of information and communication tools (IC tools) in case studies on participatory water management in nine European countries (Pahl-Wostl et al., 2007). In the final analysis of the HarmoniCOP case studies, IC tools were not included in the list of 26 key factors fostering social learning, but were listed as a (minor) barrier, mainly due to their complexity, which tends to exclude lay stakeholders (Mostert et al., 2007). In one of the cases, a Flemish river valley development initiative, the IC tools included computer models (Maurel et al., 2007). These models were developed in the course of the project to evaluate a range of scenarios with respect to flooding hazards and ecological impacts. However, the scientists were not willing to involve the stakeholders in their model-based search for alternative scenarios, because the model outcomes were highly uncertain and contested and did not confirm optimistic expectations concerning win-win solutions. The models, therefore, did not play a supporting role in social learning in this case.

\section{ATEAM}

The overarching goal of the 'Advanced Terrestrial Ecosystem Assessment and Modelling' (ATEAM) project was to produce an IA of vulnerability of European ecosystem functions to global change (Schröter et al., 2005). A stakeholder dialogue was embedded in the research process, with three general and three sectoral workshops, during which scientists presented scenarios, modelling approaches, model outcomes and conclusions on vulnerability for a range of sectors. The focus of the participatory process was threefold: to prompt critical feedback, to satisfy specific data needs for better model developments and to develop best dissemination strategies for the model outputs. Therefore, the degree of stakeholder participation in the ATEAM dialogue can best be described as a combination of informing and consulting stakeholders (de la Vega-Leinert et al., 2008). The 
discussions in the workshops focused on technical issues rather than the underlying perspectives and on stakeholder-scientist interaction rather than interaction among stakeholders, and therefore social learning is an unlikely outcome of this dialogue. Mutual learning between stakeholders and scientists was probably primarily single-loop, as the role of stakeholders was framed as providers of data and the space left for manoeuvre by scientists in addressing stakeholder feedback was rather marginal (de la VegaLeinert et al., 2008).

\section{PRELUDE}

In the 'Prospective environmental analysis of land-use development in Europe' (PRELUDE) project, the European Environmental Agency (EEA) recruited a group of about 30 stakeholders and experts to develop long-term alternative scenarios for land use in Europe (Volkery et al., 2008). The aim was to develop compelling scenario storylines to engage policy makers in 'strategic conversations', discussions about future developments and response strategies. Stakeholders were given full responsibility for identifying major driving forces and developing the scenario storylines, while experts took a supporting position and underpinned the storylines with the help of land-use simulation models. Storyline development and quantitative modelling of land-use changes were refined in an iterative process in three consecutive stakeholder workshops. The EEA found the final scenarios to be quite useful in outreach workshops for policy makers and high-level stakeholders. No formal evaluation of learning was conducted, but the outcomes suggest that the process of scenario development resulted in social learning among the stakeholders. A very heterogeneous group of stakeholders managed to formulate five very different yet consistent and interesting scenario storylines, and developed a strong trust in the validity and suitability of their problem analysis and the scenarios. The project was thus successful in bridging gaps and improving communication and collaboration between quite different stakeholders. Although quantitative modelling was important for ensuring consistency in the scenarios and for visualizing the developments with maps and graphs, it appears that it did not contribute to the social learning of stakeholders. Possible reasons are the limited opportunity for feedback between stakeholders and modellers (there was only one round of iteration from stakeholder outputs to modelling and back), and the focus of modellers on the scientific credibility of the exercise rather than its participatory and exploratory value (Volkery et al., 2008).

\section{Sustainable uplands}

The aim of this ongoing project is to combine knowledge from local stakeholders, policy makers and scientists to develop a choice of options to sustainably manage future rural change in UK uplands (Hubacek and Reed, 2009). For the study site where it is most advanced, the Peak District National Park, the project is currently in the modelling phase. Stakeholders (e.g. land managers, water companies, recreational groups, environmentalists and local policy makers) were involved through interviews and site visits in the scoping of the problem, defining the system boundaries, identifying major drivers, setting of goals and selection of sustainability indicators. Researchers produced a conceptual model (cognitive map) of the system, based on a literature review and interviews with stakeholders, and further refined this model after discussing it in a multi-stakeholder workshop. The result represented a wide variety of stakeholder knowledge and perceptions. As the conceptual model of the entire system had become highly complex, the researchers produced simpler sub-models as tools to communicate future scenarios and as starting points for group discussions. The project is designed as a social learning cycle, so the next steps are to translate the conceptual model into an integrated socio-economic and biophysical computer model, to quantify the scenarios in a spatially explicit manner, discuss the outcomes with stakeholders, identify and evaluate promising land management strategies, and formulate policy recommendations that are supported by the various stakeholder groups (Dougill et al., 2006). Although the project explicitly aims at social learning, this process has not been evaluated thus far. The integrated model will supposedly play a key role in the social learning process by allowing joint assessment of options and a feedback loop from options to goals. However, at the current stage modelling appears to have hampered social learning rather than supported it. The conceptual model, which could serve as a platform for negotiation and integration of different perspectives, was preliminarily developed by researchers and was too complex to communicate and discuss with the stakeholders. Furthermore, translating this conceptual model into an integrated computer model turned out to be technically very challenging and time-consuming. As a consequence, continuity in stakeholder participation is difficult to 
maintain, which also hinders social learning (Prell et al., 2007).

\section{Discussion}

A number of model-based PIA projects were presented and discussed as to whether and how the models supported social learning. Our analysis showed that computer models used in PIA can support social learning of stakeholders in two major ways. First of all, the model provides the link between choices and consequences that can turn the PIA process into an experiential, double-loop learning cycle when reflection on model outcomes is fed back to the problem definition stage. Second, the model provides a platform and structure for the stakeholders to communicate, negotiate and integrate their views. However, in the cases of model-based PIA that we reviewed, computer models often failed to play a significant supporting role in social learning. Concerning the first way of supporting social learning, we argue that a direct feedback loop from the assessment of model outcomes to the definition of the problem was rarely successfully established. There are several reasons for this. A major obstacle was that stakeholders often did not accept the model as a relevant representation of the problem and the system, because the spatial or temporal scale chosen for the model or the variables and indicators included did not match the interests and focus of the stakeholders. In the case of ULYSSES and VISIONS, the model could not be adapted and hence did not play a significant role. In the case of RAINS and the Delft process, the model became relevant and was used for instrumental learning only after a new 'bridging' concept was introduced in the dialogue. In these two cases, it can be argued however that the models did function as social learning tools in an indirect way by providing the means to operationalize the bridging concepts and giving these concepts the necessary scientific credibility. Another reason for the lack of a feedback loop in the presented cases was that the process design did not always allow sufficient time to establish this loop (QUEST, PRELUDE) or did not foresee such a feedback loop at all (ATEAM). Concerning the second major way in which models can support social learning, we argue that in these cases the models were used only in a very limited way as a platform for communication, negotiation and integration of a diversity of stakeholder perspectives. This was sometimes due to insufficient user-friendliness and model complexity (ULYSSES, HarmoniCOP), but a more important reason was the inflexibility of the models. Either the structure of the model predetermined by the modellers and stakeholders could only influence the options to be assessed with the model (Delft process, ULYSSES), or the models could not represent the type of issues the stakeholders were interested in (VISIONS, PRELUDE). Attempts to use existing integrated land-use models to support farmer learning at the strategic level in tropical and western agriculture have yielded similar experiences (van Paassen, 2004; Sterk, 2007).

The cases we discussed are more or less typical PIA projects, combining a broad, integrated, model-based assessment with a long-term outlook on the issue and its possible solutions. As such they represent a specific type of participatory modelling (Bots and van Daalen, 2008), and are related to other approaches in participatory modelling with a more narrow focus and/or more short-term orientation. In two of these approaches, mediated modelling (van den Belt, 2004) and companion modelling (Bousquet and Trébuil, 2005), computer models appear to be much more effective in supporting social learning than in model-based PIA. This is not surprising, as consensus-building and collective learning are explicit goals in these approaches. In both approaches, stakeholders are involved in model development from the start, through graphical interfaces or role-playing games. Stakeholders can bring in their views either by building the model together or through modellers working with highly flexible models. Frequent iterations, collective reflection on model outcomes and feedback to the definition of the problem and the range of possible solutions are important elements in both approaches. The advantage of this highly participatory approach is that the computer models used to assess options will generally be accepted by the stakeholders as salient (relevant to their concerns), legitimate (reflecting their values and interests) and credible (in accordance with their causal beliefs) (Cash et al., 2003; Stalpers et al., 2009). A drawback is that the approach is very time-consuming and resource-intensive. Even with companion modelling, focusing on local communities and well-defined problems, it takes several years to complete the whole process. Scaling-up is therefore problematic (Lynam et al., 2002; Barnaud et al., 2007), as is demonstrated by the case of the UK Sustainable Uplands project.

A more intensive participatory modelling approach similar to mediated or companion modelling may thus 
increase the effectiveness of computer models in supporting social learning, but to be feasible it must be made more efficient, given the complexity of issues and models in PIA and the usual limitations in time and resources. A number of recent developments suggest that there is scope for more efficiency in two major aspects. One aspect is the time-consuming integration of stakeholder perspectives into the complex computer models used in PIA. This is even more problematic when no consensus is reached or sought in the pre-modelling phase to prevent premature closure (van de Kerkhof, 2006), and multiple model versions are needed to represent the plurality in stakeholder views. To make the translation from stakeholder perspectives to computer models more efficient, use could be made of novel graphical, semiquantitative modelling tools such as fuzzy cognitive mapping (van Vliet et al., 2010) and qualitative probabilistic networks (van Kouwen et al., 2008), linking conceptual models effectively with simulation models. In addition or alternatively, computer models could be made more flexible, for example by anticipating stakeholder value diversity in so-called pluralistic models (van Asselt and Rotmans, 2001) or models that allow for different problem and goal definitions (Groot et al., 2007), or by using a component-based modelling framework (Ewert et al., 2009). Another aspect is the limited time that is usually available for interaction between the stakeholders and the model, often severely restricting the number of iterations and loops in the learning cycle. A range of novel tools are currently available to make the stakeholder-model interaction more efficient. Examples are three-dimensional visualization of simulated land-use changes in landscapes (Griffon et al., 2010), tools to scan interactively model outcomes (Verweij et al., 2006), interfacing of participants and the computer model through roleplaying games in a face-to-face setting (Valkering et al., 2008) or as a multi-player virtual reality game
(Wien et al., 2003), or integrating the model in a webbased virtual learning environment, which can be accessed from home (cf. Milrad et al., 2005).

Summarizing, there appear to be many options to make IA computer models more effective and efficient as social learning tools. However, critical evaluations of these options have not been conducted so far and no validated guidelines are available on how to design and combine IA computer models with other tools to effectively and efficiently support the social learning of stakeholders. This requires in-depth studies of the interaction between modelling tools and social learning processes in PIA. Up to now, evaluations of learning tools in IA have been characterized by limited attention to social-cognitive processes and are informed by only a small selection of learning theories (cf. Maurel et al., 2007). We suggest that such studies could greatly benefit from the theories and methods from the fields of group cognition and collaborative learning (O'Donnell et al., 2006; Akkerman et al., 2007), and in particular from the rapidly expanding area of computer-supported collaborative learning (CSCL) (Kirschner et al., 2003; Strijbos et al., 2004; Stahl, 2006). An example of a relevant CSCL study is the work of Beers and colleagues on tools to facilitate the negotiation of common ground in a heterogeneous group (Beers et al., 2006; Kirschner et al., 2008). In participatory modelling (e.g. Vennix, 1999), such negotiation is implicitly required but not supported. The study of Beers shows how the insights and methods from CSCL are helpful in analysing the learning process, designing learning support tools and evaluating their effectiveness. It is our expectation, therefore, that connecting the fields of PIA and collaborative learning science and technology will significantly advance our understanding of how computer models can support social learning for more sustainable environmental and natural resources management.

\section{References}

Akkerman, S., van den Bossche, P., Admiraal, W., Gijselaers, W., Segers, M., Simons, R.-J., Kirschner, P. A., 2007, 'Reconsidering group cognition: from conceptual confusion to a boundary area between cognitive and socio-cultural perspectives?', Educational Research Review 2, 39-63.

Amann, M., Cofala, J., Heyes, C., Klimont, Z., Schopp, W., 1999, 'The RAINS model: a tool for assessing regional emission control strategies in Europe', Pollution Atmosphérique 164(Special Issue), 41-64.

Argyris, C., Schön, D., 1978, Organisational Learning: A Theory of Action Perspective, Addison-Wesley Publishing Company, MA, USA.

Arnstein, S., 1969, 'A ladder of citizen participation', Journal of the American Institute of Planners 35, 16-24.

Barnaud, C., Promburom, P., Trébuil, G., Bousquet, F., 2007, 'An evolving simulation/gaming process to facilitate adaptive watershed management in northern mountainous Thailand', Simulation and Gaming 38, 398-420.

Beers, P. J., Boshuizen, H. P. A., Kirschner, P. A., Gijselaers, W., 2006, 'Common ground, complex problems and decision making', Group Decision and Negotiation 15, 529-556. 
Bohunovsky, L., Jäger, J., 2008, 'Stakeholder integration and social learning in integrated sustainability assessment', Paper presented at the 2008 Berlin Conference on the Human Dimensions of Global Environmental Change: International Conference of the Social-Ecological Research Programme.

Bots, P. W. G., van Daalen, C. E., 2008, 'Participatory model construction and model use in natural resource management: a framework for reflection', Systemic Practice and Action Research 21, 389-407.

Bousquet, F., Trébuil, G., 2005, 'Introduction to companion modeling and multi-agent systems for integrated natural resource management in Asia', in: F. Bousquet, G. Trébuil, B. Hardy (eds), Companion Modeling and Multi Agent Systems for Integrated Natural Resource Management in Asia, International Rice Research Institute, Manila.

Bouwman, A. F., Kram, T., Klein Goldewijk, K., 2006, Integrated Modelling of Global Environmental Change: An Overview of IMAGE 2.4, Netherlands Environmental Assessment Agency, Bilthoven.

Carmichael, J., Tansey, J., Robinson, J., 2004, 'An integrated assessment modeling tool', Global Environmental Change 14, 171-183.

Cash, D. W., Clark, W. C., Alcock, F., Dickson, N. M., Eckley, N., Guston, D., Jäger, J., Mitchell, R., 2003, 'Knowledge systems for sustainable development', Proceedings of the National Academy of Sciences 100, 8086-8091.

Cuppen, E., Breukers, S., Hisschemöller, M., Bergsma, E., 2010, ' $Q$ methodology to select participants for a stakeholder dialogue on energy options from biomass in the Netherlands', Ecological Economics 69, 579-591.

Dahinden, U., Querol, C., Jäger, J., Nilsson, M., 2000, 'Exploring the use of computer models in participatory integrated assessment: experiences and recommendations for further steps', Integrated Assessment 1, 253-266.

de la Vega-Leinert, A. C., Schröter, D., Leemans, R., Fritsch, U., Pluimers, J., 2008, 'A stakeholder dialogue on European vulnerability', Regional Environmental Change 8, 109-124.

Dougill, A. J., Fraser, E. D. G., Holden, J., Hubacek, K., Prell, C., Reed, M. S., Stagl, S., Stringer, L. C., 2006, 'Learning from doing participatory rural research: lessons from the Peak District National Park', Journal of Agricultural Economics 57, 259-275.

Ewert, F., van Ittersum, M. K., Bezlepkina, I., Therond, O., Andersen, E., Belhouchette, H., Bockstaller, C., Brouwer, F., Heckelei, T., Janssen, S., Knapen, M. J. R., Kuiper, M., Louhichi, K., Alkan Olsson, J., Turpin, N., Wery, J., Wien, J. E., Wolf, J., 2009, 'A methodology for enhanced flexibility of integrated assessment in agriculture', Environmental Science and Policy 12, 546-561.

Griffon, S., Auclair, D., Nespoulous, A., 2010, 'Visualising changes in agricultural landscapes', in: F. Brouwer, M. van Ittersum (eds), Environmental and Agricultural Modelling: Integrated Approaches for Policy Impact Assessment, Springer, Dordrecht, 133-158.

Groot, J. C. J., Rossing, W. A. H., Jellema, A., Stobbelaar, D. J., Renting, H., van Ittersum, M. K., 2007, 'Exploring multi-scale trade-offs between nature conservation, agricultural profits and landscape quality: a methodology to support discussions on land-use perspectives, Agriculture', Ecosystems and Environment 120, 58-69.

Hage, M., Leroy, P., 2007, Stakeholder Participation Guidance for the Netherlands Environmental Assessment Agency, MNP publication no. 550032007.

Harris, G., 2002, 'Integrated assessment and modelling: an essential way of doing science', Environmental Modelling and Software 17, 201-207.
Hisschemöller, M., Hoppe, R., 1995, 'Coping with intractable controversies: the case for problem structuring in policy design and analysis', Knowledge and Policy: The International Journal of Knowledge Transfer and Utilization 8, 40-60.

Hisschemöller, M., Tol, R. S. J., Vellinga, P., 2001, 'The relevance of participatory approaches in integrated environmental assessment', Integrated Assessment 2, 57-72.

Hubacek, K., Reed, M. S., 2009, 'Lessons learned from a computer-assisted participatory planning and management process in the Peak District National Park, England', in: C. Allen, G. Stankey (eds), Adaptive Environmental Management: A Practical Guide, Springer, Heidelberg.

Jiggins, J., Röling, N., van Slobbe, E., 2007, 'Social learning in situations of competing claims on water use', in: A. E. J. Wals (ed.) Social Learning: Towards a More Sustainable World, Wageningen Academic Publishers, Wageningen, The Netherlands.

Kasemir, B., Dahinden, U., Swartling, G., Schüle, R., Tabara, D., Jaeger, C. C., 2000, 'Citizens' perspectives on climate change and energy use', Global Environmental Change 10, 169-184.

Keen, M., Brown, V. A., Dyball, R., 2005, Social Learning in Environmental Management: Towards a Sustainable Future, Earthscan, London.

Kirschner, P. A., Buckingham Shum, S. J., Carr, C. S., 2003, Visualizing Argumentation: Software Tools for Collaborative and Educational Sense-Making, Springer, London.

Kirschner, P. A., Beers, P. J., Boshuizen, H. P. A., Gijselaers, W. H., 2008, 'Coercing shared knowledge in collaborative learning environments', Computers in Human Behavior 24, 403-420.

Kloprogge, P., van der Sluijs, J. P., 2006, 'The inclusion of stakeholder knowledge and perspectives in integrated assessment of climate change', Climatic Change 75, 359-389.

Kok, K., van Delden, H., 2009, 'Linking narrative storylines and quantitative models to combat desertification in the Guadalentín, Spain', Environment and Planning B 36, 49-66.

Kok, K., Verburg, P. H., Veldkamp, T., 2007, 'Editorial. Integrated assessment of the land system: the future of land use', Land Use Policy 24, 517-520.

Kolb, D., 1984, Experiential Learning, Prentice-Hall, Englewood Cliffs, NJ.

Leeuwis, C., 2002, 'Making explicit the social dimensions of cognition', in: C. Leeuwis, R. Pyburn (eds), Wheelbarrows Full of Frogs: Social Learning in Natural Resource Management, van Gorcum, Assen.

Leeuwis, C., Pyburn, R., (eds) 2002, Wheelbarrows Full of Frogs: Social Learning in Natural Resource Management, van Gorcum, Assen.

Leeuwis, C., Pyburn, R., Boon, A., 2002, 'Concluding reflections on social learning', in: C. Leeuwis, R. Pyburn (eds), Wheelbarrows Full of Frogs: Social Learning in Natural Resource Management, van Gorcum, Assen.

Lotze-Campen, H., 2007, Review of Experience with Existing Models and their Suitability for Integrated Sustainability Assessment (ISA), MATISSE Working Paper 16.

Lynam, T., Bousquet, F., d'Aquino, P., Barreteau, O., Le Page, C., Chinembiri, F., Mombeshora, B., 2002, 'Adapting science to adaptive managers: spidergrams, belief models, and multi-agent systems modeling', Conservation Ecology 5, 24 [online].

Maurel, P., Craps, M., Cernessona, F., Raymond, R., Valkering, P., Ferrand, N., 2007, 'Concepts and methods for analysing the role of information and communication tools (IC-tools) in social learning processes for river basin management', Environmental Modelling and Software 22, 630-639. 
Milrad, M., Spector, J. M., Davidsen, P. I., 2005, 'Model facilitated learning', in: S. Naidu (ed.), Learning and Teaching with Technology: Principles and Practices, Routledge, Oxon.

Mostert, E., Pahl-Wostl, C., Rees, Y., Searle, B., Tàbara, D., Tippet, J., 2007, 'Social learning in European river basin management: barriers and fostering mechanisms from 10 river basins', Ecology and Society 12, 19 [online].

Muro, M., Jeffrey, P., 2008, 'A critical review of the theory and application of social learning in participatory natural resource management processes', Journal of Environmental Planning and Management 51, 325-344.

O'Donnell, A. M., Hmelo-Silver, C. E., Erkens, G., (eds) 2006, Collaborative Learning, Reasoning, and Technology, Erlbaum, Mahwah, NJ.

Pahl-Wostl, C., 2002, 'Editorial of the special issue of Integrated Assessment on "Integrated Assessment and the European Water Framework Directive"', Integrated Assessment 3, 1-2.

Pahl-Wostl, C., 2009, 'A conceptual framework for analysing adaptive capacity and multi-level learning processes in resource governance regimes', Global Environmental Change 19, 354-365.

Pahl-Wostl, C., Hare, M. P., 2004, 'Processes of social learning in integrated resources management', Journal of Community and Applied Social Psychology 14, 193-206.

Pahl-Wostl, C., Craps, M., Dewulf, A., Mostert, E., Tabara, D., Taillieu, T., 2007, 'Social learning and water resources management', Ecology and Society 12, 5 [online].

Patel, M., Kok, K., Rothman, D., 2007, 'Participatory scenario construction in land use analysis: an insight into the experiences created by stakeholder involvement in the northern Mediterranean', Land Use Policy 24, 546-561.

Prell, C., Hubacek, K., Reed, M., 2006, 'Using stakeholder and social network analysis to support participatory processes', International Journal of Biodiversity Science and

Management 2, 1-4.

Prell, C., Hubacek, K., Reed, M. S., Burt, T. P., Holden, J., Jin, N., Quinn, C., Sendzimir, J., Termansen, M., 2007, 'If you have a hammer everything looks like a nail: "traditional" versus participatory model building', Interdisciplinary Science Reviews 32, 1-20.

Rittel, H., Webber, M., 1973, 'Dilemmas in a general theory of planning', Policy Sciences 4, 155-169.

Robinson, J., 2003, 'Future subjunctive: backcasting as social learning', Futures 35, 839-856.

Robinson, J., Carmichael, J., van Wynsberghe, R., Journeay, M., Rogers, L., 2006, 'Sustainability as a problem of design: interactive science in the Georgia basin', Integrated Assessment 6, 165-192.

Röling, N., 2002, 'Beyond the aggregation of individual preferences - moving from multiple to distributed cognition in resource dilemmas', in: C. Leeuwis, R. Pyburn (eds), Wheelbarrows Full of Frogs - Social Learning in Natural Resource Management, van Gorcum, Assen.

Rotmans, J., 1998, 'Methods for IA: the challenges and opportunities ahead', Environmental Modelling and Assessment 3, 155-179.

Rotmans, J., 2006, 'Tools for integrated sustainability assessment: a two-track approach', The Integrated Assessment Journal 6, 35-57.

Rotmans, J., van Asselt, M., Anastasi, C., Greeuw, S., Mellors, J., Peters, S., Rothman, D., Rijkens, N., 2000, 'Visions for a sustainable Europe', Futures 32, 809-831.

Sabatier, P. A., 1988, 'An advocacy coalition framework of policy change and the role of policy-oriented learning therein', Journal of Policy Sciences 21, 129-168.

Schlumpf, C., Behringer, J., Durrenberger, G., Pahl-Wostl, C., 1999, 'The personal $\mathrm{CO}_{2}$-calculator: a modeling tool for participatory integrated assessment methods',

Environmental Modeling and Assessment 4, 1-12.

Schröter, D., Cramer, W., Leemans, R., Prentice, I. C., Araújo, M. B., Arnell, N. W., Bondeau, A., Bugmann, H., Carter, T. R., Garcia, C. A., de la Vega-Leinert, A. C., Erhard, M., Ewert, F., Glendining, M., House, J. I., Kankaanpää, S., Klein, R. J. T., Lavorel, S., Lindner, M., Metzger, M. J., Meyer, J., Mitchell, T. D., Reginster, I., Rounsevell, M., Sabaté, S., Sitch, S., Smith, B., Smith, J., Smith, P., Sykes, M. T., Thonicke, K., Thuiller, W., Tuck, G., Zaehle, S., Zierl, B., 2005, 'Ecosystem service supply and vulnerability to global change in Europe', Science 310, 1333-1337.

Shapka, J. D., Law, D. M., van Wynsberghe, R., 2008, 'Quest for communicating sustainability: Gb-Quest as a learning tool for effecting conceptual change', Local Environment 13, 107-127.

Siebenhüner, B., 2002, 'How do scientific assessments learn? Part 2. Case study of the LRTAP assessments and comparative conclusions', Environmental Science and Policy 5, 421-427.

Siebenhüner, B., Barth, V., 2005, 'The role of computer modelling in participatory integrated assessments', Environmental Impact Assessment Review 25, 367-389.

Stahl, G., 2006, Group Cognition: Computer Support for Building Collaborative Knowledge, MIT Press, Cambridge, MA.

Stalpers, S. I. P., van lerland, E. C., Kroeze, C., 2009, 'Reconciling model results with user needs to improve climate policy', Environmental Science and Policy 12, 959-969.

Sterk, B., 2007, 'A window of opportunities. The contributions of land use modelling to societal learning', Doctoral thesis, Wageningen University.

Strijbos, J.-W., Kirschner, P. A., Martens, R. L., 2004, 'What we know, don't know and need to know about CSCL', in: $P$. Dillenbourg (Series ed.), J. W. Strijbos, P. A. Kirschner, R. L. Martens (Vol. eds), Computer-Supported Collaborative Learning: Vol. 3. What We Know About CSCL ... and Implementing it in Higher Education, Kluwer Academic Publishers, Boston, MA, 245-260.

Tuinstra, W., Hordijk, L., Amann, M., 1999, 'Using computer models in international negotiations - the case of acidification in Europe', Environment 41(9), 33-42.

Tuinstra, W., Jäger, J., Weaver, P. M., 2008, 'Learning and evaluation in integrated sustainability assessment', International Journal of Innovation and Sustainable Development 3, 128-152.

Valkering, P., Offermans, A., Tàbara, D., Wallman, P., Elmqvist, B., Ewald, G., Martens, P., 2008, Modelling Cultural and Behavioural Change in Water Management: An Integrated, Agent-Based, Gaming Approach. MATISSE Working Paper 25.

van Asselt, M. B. A., Rotmans, J., 2001, 'Uncertainty in integrated assessment modelling - from positivism to pluralism', Climatic Change 54, 75-105.

van Daalen, C. E., Thissen, W. A. H., Berk, M. M., 1996, 'The Delft process: experiences with a dialogue between policy makers and global modellers', Global Environmental Change 6, 267-285

van de Kerkhof, M., 2006, 'A dialogue approach to enhance learning for sustainability', The Integrated Assessment Journal 6, 7-34

van den Belt, M., 2004, Mediated Modelling: A Systems Dynamic Approach to Environmental Consensus Building, Island Press, Washington, DC.

van Ittersum, M. K., Ewert, F., Heckelei, T., Wery, J., Alkan Olsson, J., Andersen, E., Bezlepkina, I., Brouwer, F., Donatelli, M., Flichman, G., Olsson, L., Rizzoli, A. E., van der Wal, T., Wien, J. E., Wolf, J., 2008, 'Integrated assessment of 
agricultural systems - A component-based framework for the European Union (SEAMLESS)', Agricultural Systems 96, $150-165$.

van Kouwen, F. A., Schot, P. P., Wassen, M. J., 2008, 'A framework for linking advanced simulation models with interactive cognitive maps', Environmental Modelling \& Software 23, 1133-1144.

van Paassen, A., 2004, 'Bridging the gap: computer model enhanced learning about natural resource management in Burkina Faso', Doctoral thesis, Wageningen University.

van Vliet, M., Kok, K., Veldkamp, T., 2010, 'Linking stakeholders and modellers in scenario studies: the use of fuzzy cognitive maps as a communication and learning tool', Futures 42, 1-14.

Vennix, J. A. M., 1999, 'Group model-building: tackling messy problems', System Dynamics Review 15, 379-401.
Verweij, P. J., Sieber, S., Wien, J. J. F., Müller, K., 2006, 'SIAT a sustainable impact assessment tool for understanding the drivers in integrated impact assessment', Paper presented at the International Conference IEMSS, Vermont, USA. Volkery, A., Ribeiro, T., Henrichs, T., Hoogeveen, Y., 2008, 'Your vision or my model? Lessons from participatory land use scenario development on a European scale', Systemic Action and Practice Research 21, 459-477. Wals, A. E. J. (ed.), 2007, Social Learning: Towards a More Sustainable World, Wageningen Academic Publishers, Wageningen, The Netherlands.

Wien, J. J. F., Otjens, A. J., van der Wal, T., 2003, 'ICT tools for participatory planning', Paper presented at the European Federation for Information Technology in Agriculture, Food, and the Environment (EFITA) Conference, Debrecen, Hungary, 5-9 July. 